\title{
A reinvenção do paternalismo: a Companhia Paulista de Estradas de Ferro entre as décadas de 1920 e 1940
}

\section{The reinvention of paternalism: the Paulista Railway Company between the 1920s and 1940s}

\author{
Luciana Massami Inoue ${ }^{1, *}$ (D) 0000-0002-6683-1443
}

Guilherme Grandi ${ }^{1}$ (D) 0000-0002-6040-0650

${ }^{1}$ Universidade de São Paulo, São Paulo, Brasil.

*Correspondencia: lumassami@gmail.com

Resumo. Analisa-se neste artigo a estratégia empresarial da Companhia Paulista de reinventar relações paternalistas de produção no âmbito da atividade ferroviária em São Paulo entre os anos 1920 e 1940. Responsáveis por instituírem uma série de instrumentos de controle sobre o trabalho em escala industrial, as companhias de estradas de ferro exerceram influência decisiva sobre as relações de trabalho, tanto por meio de suas atividades de operação do serviço de transporte quanto de manutenção do material ferroviário realizado nas oficinas de construção e reparo. Dentre os instrumentos capazes de manter a lógica paternalista das relações de produção no setor ferroviário, as vilas operárias constituem um dos mais efetivos no controle do capital sobre a mão de obra, em virtude do impacto causado sobre a vida privada e familiar dos ferroviários.

Palavras-chave: Paternalismo; ferrovia; relações de produção; vila ferroviária; Companhia Paulista de Estradas de Ferro.

CÓMO CITAR: Grandi, G. e Inoue, L. M. (2021). A reinvenção do paternalismo: a Companhia Paulista de Estradas de Ferro entre as décadas de 1920 e 1940. América Latina en la Historia Económica, 28(1), 1-23. DOI: 10.18232/alhe.1084 
Abstract. This paper analyze the business strategy of Companhia Paulista to reinvent paternalistic production relations within the scope of the railway activity in São Paulo between 1920 and 1940. Responsible for establishing a series of control instruments on industrial scale work, railway companies had decisive influence on labor relations, both through its operation activities of transportation service and maintenance of railway material carried out in construction and repair workshops. Among the tools for maintaining the paternalistic logic of production relations in the railway sector, workers' villages was one of the most effective capital control over labor, due to the impact on the private life and families of railway workers.

Key words: Paternalism; railway; production relations; railway village; Paulista Railway Company.

JEL: N76; N86; N96.

Recebido: 3 de junho de 2019.

Aceito: 24 de setembro de 2019 .

Publicado: 7 de outubro de 2020.

\section{INTRODUÇÃO}

As relações de trabalho que vigoravam no interior das companhias paulistas de estradas de ferro experimentaram mudanças profundas, principalmente a partir do período posterior à Primeira Guerra Mundial, quando uma nova estrutura urbana-industrial se consolidou em cidades como São Paulo e Rio de Janeiro, em função da intensificação do movimento de Substituição de Importações da economia brasileira acarretado pelo conflito bélico. Tal incremento do produto industrial no Brasil foi acompanhado, como era de se esperar, por um aumento do emprego da mão de obra em diversos segmentos industriais, o que, por sua vez, passou a exigir novas formas de gerenciamento, treinamento e organização de uma massa crescente de trabalhadores assalariados.

Dentre os ramos da indústria que empregavam contingentes expressivos de trabalhadores, o setor ferroviário foi o que mais se esforçou no sentido de buscar formas de se adaptar a esse novo contexto das relações de trabalho no país $1^{1}$ As ferrovias paulistas, bem como a Estrada de Ferro Central do Brasil, no Rio de Janeiro, assumiram a vanguarda desse movimento de transformação das relações de trabalho entre os dois últimos decênios do século xix e os anos 1920, em virtude da adoção de uma série de novas práticas gerenciais aplicada à formação e capacitação da sua mão de obra. Na virada dos anos 1920 para os 1930, tais medidas estavam fundamentadas pelos princípios que norteavam a chamada organização científica do trabalho, de inspiração taylorista $2^{2}$ Segnini (1982), que analisou em detalhes as relações de produção na Companhia Paulista de Estradas de Ferro, objeto privilegiado deste artigo, subdivide a trajetória da empresa em três fases: $a$ ) de 1868, ano de fundação da Companhia, a 1885, é a fase de total dominação da gerência ferroviária sobre a dinâmica do trabalho numa relação do tipo coercitiva, marca indelével da sociedade escravocrata da época; $b$ ) de 1885 a 1928, é a fase caracterizada pelo paternalismo nas relações de produção, que assinala um período de aumento das pressões dos trabalhadores sobre a burocracia e a direção da empresa. Diante do aumento da frequência das reivindicações por melhores condições de trabalho e de vida, a gestão ferroviária passa a ver suas possibilidades de expansão e acumulação de capital sujeitas à implantação de novos instrumentos de controle e dominação da

\footnotetext{
${ }^{1}$ A respeito, ver Caetano (1986).

${ }^{2}$ Há uma vasta bibliografia sobre tal temática. Contudo, para os propósitos deste artigo, destacamos os trabalhos de Antonacci (1993), Garcia (1992), Moreira (2008), Segnini (1982), Tenca (2006) e Zanetti e Vargas (2007).
} 
mão de obra. Dentre os principais instrumentos criados nessa fase paternalista, Segnini (1982) aponta a Sociedade Beneficente, a Associação Protetora das Famílias dos Empregados, a Escola de Aprendizes, a Cooperativa de Consumo e a construção e locação de casas aos ferroviários, bem como a própria formação das vilas ferroviárias; e $c$ ) entre 1928 e 1961, tem-se a fase marcada pela reforma administrativa de 1928, que consiste na resposta científica encontrada pela Companhia visando dar continuidade ao exercício da dominação sobre a mão de obra, de modo a garantir uma margem de lucro satisfatória. É a fase conhecida pela literatura como o da organização racional do trabalho e da implantação da escola de seleção e formação de ferroviários.

Não por acaso, Grandi (2013, p. 286) é categórico ao afirmar que a Companhia Paulista es a ferrovia nacional mais bem-sucedida do Brasil entre 1930 e meados de 1950 (ver tabela 1). Nota-se que, até o ano de 1953, a Paulista nunca havia gerado um coeficiente de tráfego superior a $90 \%$, índice padrão de lucratividade operacional das estradas de ferro que indica a participação das despesas sobre a receita do serviço ferroviário.

Este artigo procura avaliar como se deu o desenvolvimento de cada um desses instrumentos de organização do trabalho ferroviário nas diferentes fases da Companhia Paulista (seções 2 e 3 do artigo), tendo como limite temporal a década de 1940. Mais adiante (seção 4) se aborda especificamente à análise das vilas ferroviárias, as quais considera-se um dos instrumentos de grande eficácia para o controle e monitoramento da mão de obra empregada nas ferrovias paulistas. Por último (seção 5), conclui o trabalho ao pontuar que a Paulista, bem como outras companhias ferroviárias congêneres, procurou reinventar sistematicamente relações paternalistas de produção ${ }^{3}$ marcadas pela retórica empresarial da racionalização e do cientificismo dos processos de produção e que se expressavam constantemente por meio da redefinição das relações de trabalho nas diversas seções departamentais que compunham a estrutura produtiva-organizacional das estradas de ferro de São Paulo.

Via de regra, o paternalismo, conceito do qual ocupa também neste artigo, tem a função de assegurar a dominação do capital sobre o trabalho, já que empresas organizadas sob tal modelo de gestão procuram atender às necessidades dos seus funcionários em troca de um comportamento que denote gratidão e lealdade à empresa. Nesse passo, a aceitação do domínio se dá por meio da disciplina e da subordinação irrestrita à gerência empresarial, além do esforço constante dos subordinados em corresponder às expectativas patronais relativas aos objetivos da empresa, como observado por Teixeira (1984). Já para Huberman (1987, p. 81), o paternalismo representa um incentivo a patrões e empregados estabelecerem relações harmoniosas de longo prazo.

\footnotetext{
${ }^{3} \mathrm{~A}$ historiografia especializada no tema costuma diferenciar o paternalismo que surge com as primeiras fábricas têxteis britânicas do chamado novo paternalismo, associado ao período de 1850 a 1874 . O primeiro tinha por finalidade formar e preparar a mão de obra rural para o modelo disciplinar exigido pela produção fabril, ao passo que o segundo conceito se relaciona mais à negociação entre patrões e empregados em torno de uma ideologia de cooperação que favoreça a consolidação de uma cultura urbana pautada na harmonia social. A esse respeito, ver Joyce (1980) e Revill (2001). É importante ressaltar que o sentido conceitual adotado em este artigo está mais próximo da ideia do novo paternalismo do que do paternalismo clássico vinculado à cultura fabril vitoriana. Para uma análise sobre o paternalismo aplicado ao caso do setor ferroviário no Canadá durante os anos 1850 ver Craven e Traves (1986).
} 
TABELA 1. CIA. PAULISTA: RESULTADO OPERACIONAL E COEFICIENTE DE TRÁFEGO, 1930-61 (VALORES NOMINAIS)

\begin{tabular}{|c|c|c|c|}
\hline Anos & Receita (en mil-réis) & Despesa (en mil-réis) & Coeficiente (\%) \\
\hline 1930 & 85579312 & 57300580 & 67 \\
\hline 1931 & 86516534 & 57422187 & 66.4 \\
\hline 1932 & 103740473 & 52655463 & 50.8 \\
\hline 1933 & 93729231 & 53849614 & 57.5 \\
\hline 1934 & 107481254 & 58021502 & 54 \\
\hline 1935 & 103166790 & 66440902 & 64.4 \\
\hline 1936 & 116324283 & 71239513 & 61.2 \\
\hline 1937 & 125522529 & 75093949 & 59.8 \\
\hline 1938 & 140474919 & 90027137 & 64.1 \\
\hline 1939 & 140313759 & 89890220 & 64.1 \\
\hline 1940 & 131098386 & 92117095 & 70.3 \\
\hline 1941 & 141509147 & 98090448 & 69.3 \\
\hline 1942 & 158824986 & 110242072 & 69.4 \\
\hline 1943 & 185226334 & 130614228 & 70.5 \\
\hline 1944 & 234682396 & 180478793 & 76.9 \\
\hline 1945 & 284124636 & 231520785 & 81.5 \\
\hline 1946 & 350524802 & 282904370 & 80.7 \\
\hline 1947 & 395847206 & 341796368 & 86.3 \\
\hline 1948 & 399986811 & 340458196 & 85.1 \\
\hline 1949 & 447271016 & 387333651 & 86.5 \\
\hline 1950 & 469224087 & 406651463 & 86.6 \\
\hline 1951 & 581268661 & 490884487 & 84.4 \\
\hline 1952 & 687750466 & 613442698 & 89.2 \\
\hline 1953 & 755032211 & 701823111 & 92.7 \\
\hline 1954 & 910446762 & 817890086 & 89.8 \\
\hline 1955 & 1121557196 & 1030845467 & 91.8 \\
\hline 1956 & 1321617702 & 1268590625 & 95.9 \\
\hline 1957 & 1643093868 & 1571016159 & 95.6 \\
\hline 1958 & 1797303420 & 1668311273 & 92.8 \\
\hline 1959 & 2360207497 & 2248999836 & 95.2 \\
\hline 1960 & 2549413059 & 2502195447 & 98.1 \\
\hline 1961 & 3546531797 & 4205992466 & 118.6 \\
\hline
\end{tabular}

Fonte: Grandi (2013, pp. 190-191). 


\section{FORMAÇÃO E DISCIPLINAMENTO DA MÃO DE OBRA FERROVIÁRIA}

Os mecanismos paternalistas de controle das relações de produção da Companhia Paulista foram sendo sistematicamente redefinidos a partir do final da década de 1920, de modo que a Escola de Aprendizes se transformou, em 1934, na Escola de Ferroviários, tendo à sua frente o engenheiro mecânico Roberto Mange ${ }^{4}$ uma das figuras responsáveis por introduzir no Brasil os princípios técnicos do taylorismo, do fordismo e da racionalização e organização científica do trabalho.

Mange teve um papel de destaque no movimento de institucionalização do ensino e capacitação técnica da mão de obra industrial no país ao participar ativamente da fundação do Instituto de Organização Racional do Trabalho (IDORT), em 1931, e da organização das seguintes escolas de formação profissional: Centro Ferroviário de Ensino e Seleção Profissional (CFEsP), em 1934, Serviço Nacional de Aprendizagem Industrial (sENAI): ${ }^{5}$ de 1942, e Serviço Social da Indústria (SEsI), de 1946 (Tenca, 2006, p. 74).

Desde o início do século xx, a diretoria da Companhia Paulista já havia reconhecido a importância do processo de aprendizagem para a adequação do trabalho ferroviário aos objetivos da empresa. Fundada em 1901, a Escola de Aprendizes conseguiu cumprir adequadamente o seu papel até meados dos anos 20. A seleção era feita entre os próprios filhos dos ferroviários, garantindo assim a formação da família ferroviária, que preservava certa moral do trabalho e se mostrava perfeitamente enquadrada na ideologia disciplinadora imposta e difundida pela empresa.

Com o passar do tempo, e diante da evolução das atividades da companhia, o processo de ensino e formação profissional deixou de atender a contento as necessidades da grande rede ferroviária que vinha sendo formada pelas linhas da Companhia Paulista. Era um processo moroso e pouco rentável de acordo com os engenheiros-chefes da estrada e que, portanto, exigia uma solução imediata não somente da Paulista, mas de todas as outras grandes ferrovias do estado de São Paulo que estavam, àquela altura, sujeitas ao mesmo desafio quanto à boa formação técnica da mão de obra ferroviária.

Frente a tal desafio, a Companhia Paulista integrou-se em 1924 a um conjunto de quatro empresas ferroviárias que se conveniaram ao Liceu de Artes e Ofícios de São Paulo ${ }^{6}$ O objetivo desse convênio era o de viabilizar uma nova experiência de formação dos seus quadros de funcionários ao aceitar o processo de seleção e treinamento sob a orientação do próprio Mange. Assim, criou-se a Escola Profissional do Liceu de Artes e Ofícios à luz dos critérios de racionalização e organização científica do trabalho. Ao se mostrar exitosa para os intentos do capital ferroviário, tal experiên-

\footnotetext{
${ }^{4}$ Nascido em 1885 em La Tour de Peilz, cantão de Vaud (Suíça), Roberto Auguste Edmond Mange formou-se engenheiro mecânico em 1910 pela Eidgenoessische Technische Hochschule, localizada em Zurique, depois de passar alguns anos em Portugal, onde conclui a escola primária em 1899, e na Alemanha, onde passou alguns anos no curso secundário. Chega a São Paulo em junho de 1913 a convite do engenheiro Antônio Francisco de Paula Souza para lecionar na Escola Politécnica, criada em 1894. Sua missão era propor soluções para o problema da falta de mão de obra especializada, tanto para a indústria quanto para atender às necessidades decorrentes do crescimento da cidade de São Paulo e da expansão das estradas de ferro (Tenca, 2006, pp. 74-75).

${ }^{5}$ No SENAI, Mange foi o primeiro diretor a ocupar o cargo até sua morte em 1955.

6 “Inaugurada em 1923, a Escola Profissional de Mecânica, anexa ao Liceu de Artes e Ofícios de São Paulo, pode ser apontada por ter lançado a semente para a formação da primeira experiência de coordenação do ensino ferroviário, cujo propósito foi o de ampliar o controle de seus trabalhadores, através da educação profissional" (Caetano, 1986, p. 237). Antonacci (1987, p. 67) tece uma interpretação ainda mais crítica ao enfatizar que o curso de Mecânica Prática, criado pelo Liceu de Artes e Ofícios e dirigido por Roberto Mange, visava forjar a “adaptação psicofísica do homem à máquina a fim de aumentar o rendimento do trabalho, diminuir a fadiga e os riscos de acidentes e atingir novos níveis de disciplinarização da força de trabalho [...]”.
} 
cia seria ampliada em 1934 por meio da criação do CFESP, como observa Segnini (1982, p. 75). Além da Paulista, aderiram ao CFESP as seguintes companhias: E. F. Araraquarense, E. F. Campos do Jordão, Companhia Mogiana de Estradas de Ferro, Companhia Ferroviária São Paulo-Goiás, Companhia E. F. do Dourado e a Companhia E. F. Sorocabana.

Tempos depois, por volta de 1946, ocorreu a substituição dos professores das aulas teóricas e práticas pelos próprios ex-alunos formados entre as primeiras turmas e que apresentaram os melhores desempenhos durante o curso. Além disso, as aulas teóricas, que de início eram oferecidas exclusivamente nas escolas profissionais como a Escola Profissional Secundária de Rio Claro, foram transferidas para as oficinas das companhias ferroviárias onde ocorriam as aulas práticas. Essa mudança, ao transformar o curso de ferroviário em um curso integral, consistiu num marco importante dentro da trajetória de formação profissional da categoria ferroviária em São Paulo. A ampliação da carga horária do curso oferecido nas oficinas das companhias visava, segundo Tenca (2006, p. 89), o atendimento de mais um objetivo da gestão ferroviária: o treinamento rígido e a adaptação mais efetiva do aprendiz à rotina e à disciplina do trabalho ferroviário. A Companhia Sorocabana foi a primeira empresa ferroviária a adotar essa iniciativa de trazer o curso de formação da sua mão de obra para as dependências da empresa, seguida pela Paulista que instalou suas escolas profissionalizantes nas oficinas de Jundiaí e Rio Claro. Assim, esse movimento daria início ao processo de dissolução do CFESP, já que cada companhia passaria a manter sua própria escola de seleção e formação profissional. A partir dos depoimentos de ex-ferroviários da Paulista, é possível captar, com mais precisão, o propósito central desses cursos de formação que eram oferecidos pelo CFESP em parceria com as estradas de ferro acima mencionadas:

[O aluno saía do Curso de Ferroviário] não digo engenheiro, mas com uma posição média. Ele tinha um conhecimento prático que o engenheiro não tinha, e um conhecimento teórico que o artífice não tinha. E foi com essa finalidade mesmo que foi fundado esse Curso, para conseguir pessoas de um nível médio que pudessem fazer a ligação do engenheiro com os artífices. Esse era o objetivo do Curso (Depoimento de Walter Lucke. In Tenca, 2006, p. 81).

E na verdade isso aconteceu. Chegou uma época em que, na maioria das seções, o chefe já era ex-aluno do Curso de Ferroviários. E tinha que ser, quer queira quer não! Mesmo um pouco antes de eu sair aposentado, já não existia, eu acho, seção nenhuma em que o chefe não fosse ex-aluno. Salvo raras exceções. Mas a maioria era de pessoas que foram alunos (Depoimento de Euclides Guilherme. In Tenca, 2006, p. 81).

Como já pontuamos, datam também dos anos 40 a criação do SENAI (em 1942), além do SESI e do SESG (em 1946). Assim, podemos afirmar que a CFESP foi perdendo sua função à medida que suas atividades de formação e capacitação da mão de obra ferroviária foram sendo incorporadas por essas novas instituições de ensino. Entretanto, para selecionar e formar seus próprios funcionários, as estradas de ferro optaram por manter as escolas de aprendizagem em suas oficinas sob a supervisão em tempo integral dos seus mestres e contramestres e, o que também é fundamentalmente importante, sem qualquer interferência regulatória do Estado. 


\section{A dimensão assistencialista do Paternalismo na Companhia Paulista}

Dentre os benefícios -ou instrumentos de controle- tipicamente paternalistas existentes desde o início da operação ferroviária da Companhia Paulista haviam as cooperativas de consumo e o pecúlio dado às famílias em caso de morte dos trabalhadores, ou desligamento por invalidez como consequência de acidentes de trabalho. Contudo, há controvérsias sobre se a iniciativa de concessão desse segundo benefício partiu dos próprios trabalhadores, mediante a atuação das associações mutualistas e/ou ligas operárias, ou foi uma resolução criada e implementada por iniciativa própria da companhia.

Criadas em 1902, as cooperativas de consumo forneciam gêneros alimentícios e outras mercadorias (como tecidos, utensílio doméstico, etc.) aos seus funcionários por preços, via de regra, considerados mais acessíveis comparados aos preços de mercado. As compras dos ferroviários feitas nas cooperativas eram, em geral, descontadas diretamente da folha de pagamentos. Foram instaladas cooperativas em Jundiaí, Campinas, Dois Córregos e São Carlos, municípios dotados de grandes armazéns de secos e molhados. Os pedidos podiam ser realizados de qualquer cidade para as cooperativas e estas despachavam as encomendas através dos próprios comboios ferroviários. Pelos depoimentos coligidos por Ferreira (2010, p. 43), parece que os empregados da Paulista aprovavam a iniciativa, uma vez que os produtos comercializados eram adquiridos a preços mais módicos dos praticados no comércio regular das cidades onde a ferrovia mantinha suas estações.

No entanto, ao examinarmos a documentação produzida pela Liga Operária de Jundiaí (1906) - organização embrionária do sindicato dos ferroviários da Paulista- encontramos uma outra versão acerca da opinião dos ferroviários sobre as cooperativas de consumo e a chamada Sociedade Beneficente dos Empregados da Companhia Paulista. O contexto da primeira grande greve ferroviária de 19067 é emblemático nesse sentido, pois dentre as razões do movimento grevista listadas pelos membros da Liga encontramos queixas como a que se segue:

Os abusos e irregularidades praticadas na Sociedade Beneficente entre os empregados da Comp. Paulista, dando lugar de médico e farmacêutico da mesma, a parentes e afiliados, sendo o médico da sessão de Campinas próximo parente de Monlevade, e o de Rio Claro, idem: os demais são afiliados [...] Incompatibilidade do chefe das farmácias, o qual exerce contemporaneamente os cargos de engenheiro, farmacêutico, professor de escola e dedica-se ao comércio, negociando com arroz e feijão, enquanto a responsabilidade das farmácias fica entregue a um pessoal pouco sério, nem habilitado para assumi-la. Manda-se vir gêneros do interior para a 'Cooperativa' e, como a Comp. não cobra frete das cargas àquela destinadas, é lógico que resultando daí uma diferença a favor do preço dos artigos, os engenheiros afiliados aproveitam essa circunstância para negociar (Liga Operária de Jundiaí, 1906).

A Associação Protetora das Famílias dos Empregados foi criada em 1904 com a finalidade de fornecer às famílias dos sócios um pecúlio por motivo de acidente de trabalho ou falecimento. Ferreira (2010, pp. 44-45) afirma que se tratava de uma iniciativa dos próprios ferroviários da Paulista. Zambello (2005, p. 100) também concorda com essa visão ao notar que já em 1901 os trabalhadores possuíam “uma organização própria, como a Sociedade Beneficente dos Empregados em Locomotiva da Companhia Paulista de Estradas de Ferro, fundada por maquinistas e foguistas”. Anos depois,

${ }^{7}$ A respeito dessa greve dos ferroviários da Paulista, ver Grandi (2014). 
em 1910, criou-se o Fundo Especial de Pensões com o mesmo objetivo de auxiliar os mais velhos e as vítimas de acidentes de trabalho. Os primeiros registros de reivindicação dos ferroviários da Paulista para a criação deste fundo remontam ao ano de 1908 e os valores das contribuições destinadas ao fundo constam nos relatórios semestrais da companhia.

Segnini (1982, p. 43) observa que a Liga Operária dos ferroviários da Paulista foi criada pelos trabalhadores da ferrovia exclusivamente para representar e defender os interesses da classe junto às negociações com a diretoria da empresa. Por outro lado, a forma encontrada pela empresa para comprometer o raio de ação da Liga Operária foi, justamente, a criação da Sociedade Beneficente dos Empregados da Companhia Paulista. Administrada pela direção da empresa e tendo em sua presidência o chefe da Locomoção, Francisco Paes Leme de Monlevade, o objetivo, segundo os Estatutos da Sociedade Beneficente, era o de prestar assistência médica aos ferroviários. Para tanto, descontava-se do salário dos ferroviários as contribuições no valor de três mil réis $(3 \$ 000)$ mensais.

A documentação da Liga Operária de Jundiaí ilustra bem a opinião dos ferroviários da Paulista a esse respeito:

Antipatia geral do pessoal da Cia. para com o sr. Monlevade devido a guerra implacável que este dr. faz à Liga Operária não querendo reconhecer para os operários direito de associação, direito que em nada prejudica o bom andamento do serviço, direito reconhecido e aceito por todas as nações do mundo [...] Logo que recebeu aviso da formação da Liga foi especialmente em Campinas entender-se e tentar um acordo com o dr. Carlos Estevenson, Chefe da Locomoção da Cia. Mogiana, a fim de unidos para o mesmo objetivo, procurar o cancelamento e a morte da 'Liga Operária' [...] Ele não tinha necessidade de dispensar o pessoal subalterno e lançar na miséria algumas centenas de chefes de famílias. Podia em primeiro lugar diminuir muitos doutores que nada fazem, e cuja presença não é justificada pelas exigências do serviço, posto que a Cia. Mogiana com muito mais quilômetros de linha ocupa a quarta parte dos engenheiros que são ocupados pela Cia. Paulista por nepotismo, parentesco, etc. O dr. Monlevade podia mandar construir nas oficinas da Cia. todos os maquinismos que manda vir da Europa e da América. Se assim ele tivesse procedido teria recebido o aplauso de todos os operários, porque teria dessa forma conciliado os interesses da Cia. Paulista com os interesses dos operários (Liga Operária de Jundiaí, 1906).

O que se pode depreender do trecho acima é que os ferroviários membros da Liga Operária não apenas repudiavam a figura autoritário do engenheiro Monlevade como também reprovavam uma série de ações tomadas por ele no exercício de sua função como Chefe do Departamento de Locomoção da Paulista.

A organização das primeiras ligas operárias em São Paulo ficou a cargo de alguns poucos grupos de trabalhadores artesanais, cujas fileiras excluíam, pelo menos incialmente, operários fabris comuns e trabalhadores rurais. A falta de disposição do empresariado em reconhecer a autonomia dos grupos de trabalhadores, que buscavam se organizar visando a aquisição de direitos e melhores condições de trabalho, era um dos principais obstáculos enfrentados pela liderança operária no estado. Aliado a isso, a emergente classe dos industriais paulistas atuava muitas vezes de modo semelhante à tradicional oligarquia rural, acostumada a impor uma coerção violenta sobre os trabalhadores, fossem eles escravos, nacionais livres, ex-cativos e até imigrantes. Uma mentalidade 
que descendia diretamente da longa e resiliente trajetória do sistema escravista no Brasil. Tal fato, associado com a quase total ausência de um código mínimo de leis trabalhistas no país, criava as condições para que os empregadores agissem de maneira cruel e arbitrária em seu objetivo de explorar ao máximo a mão de obra empregada. Há evidências de que as relações de trabalho pouco importavam aos dirigentes da maioria das companhias de estradas de ferro de São Paulo na virada do século xix para o xx. A respeito, especificamente da Paulista, Mattoon Jr. (1971, p. 199) salienta que "the almost total lack of descriptive information about working conditions suggests that the care and well-being of low-ranking employees was less than a constant preoccupation of Company directors".

Quanto ao Fundo Especial de Pensões de 1910, o qual já mencionamos, houve uma mudança significativa em seu funcionamento a partir de 1923, quando se sancionou a Caixa de Aposentadoria e Pensões em decorrência da aprovação da Lei Eloy Chaves (lei federal num. 4682). Segundo Segnini (1982, p. 55), tal lei foi decisiva para a criação do sistema previdenciário brasileiro. Assim, os ferroviários, tanto os mensalistas como os diaristas com serviço de caráter permanente, passaram a ter direito à aposentadoria, ao atendimento médico em casos de doenças, incluindo casos que envolvessem seus familiares, aos medicamentos obtidos por preço especial determinado pelo conselho de administração da Caixa de Aposentaria e à pensão para herdeiros em caso de morte. A passagem a seguir, do relatório da Companhia Paulista de 30 de junho de 1910, ilumina bem essa questão:

A Companhia não tem regateado a sua assistência a quantos, pelo merecimento de sua vida de trabalho, se hão recomendado a aposentadoria. Também tem ella amparado com os recursos mais necessários as famílias de seus servidores, quando deixadas em condições precárias, bem como as daqueles que succumbiram victimas de acidentes. Para atender as necessidades de semelhante ordem costumava a Companhia conceder anualmente a quota de 50:000\$000 de réis à Sociedade Beneficente dos Empregados da Companhia Paulista, que tinha a sua conta o serviço das pensões, e que, para atender aos respectivos encargos, chegara a constituir um fundo da importância de 200:000\$000. Tendo, porém, a Sociedade Beneficente proposto e a Directoria reconhecido de conveniência correr diretamente por conta da Companhia o serviço de pensões, revertendo-lhe o saldo do fundo que possuía a Sociedade e cessando o pagamento da quota annual que lhe era abonada, começou a Companhia a partir do segundo semestre do anno próximo findo, a custear esse serviço, cuja despesa actualmente importa em cerca de 50:000\$000 de réis por anno. Convindo crear um fundo especial para atender aos encargos provenientes dessa origem, no interesse de manter a verba destinada às pensões ao abrigo de eventualidades e independente da receita ordinária da Companhia, deliberou a Directoria reservar para esse fim a quantia de 500:000\$000 de réis, na distribuição do saldo geral apurado no último exercício, quantia que vae ser empregada em títulos de renda. Esse fundo será aumentado, nos anos futuros, se a isso anuirdes, com as quotas que seria possível levar a seu credito, até atingir o valor suficiente a fazer face aos encargos para que é ele constituído (Companhia, 1910, pp. 8-9). 
Cabe acrescentarmos que, como entidades públicas autônomas reguladas pelo governo, as caixas de aposentadoria dos ferroviários eram formadas por um fundo constituído mediante o desconto de $3 \%$ do salário mensal dos empregados e de $1 \%$ da renda bruta das empresas. Além dessas duas fontes, o fundo contava também com uma quantia arrecadada pelo governo federal diretamente do público usuário por meio das taxas dos serviços ferroviários.

A definição ulterior da legislação previdenciária nacional foi o resultado da aprovação da supradita Lei Eloy Chaves. Por meio dela, cada companhia ferroviária passou a manter a sua própria caixa de aposentadoria e pensões. Mais tarde, na década de 1930 o Sindicato Ferroviário de São Paulo apresentou uma proposta de unificação de tais caixas em uma única instituição. Tal medida se tornou viável com a criação, no governo de Getúlio Vargas, do Instituto de Aposentadoria e Pensões, subordinado ao Ministério do Trabalho, Indústria e Comércio. Aliás, o governo varguista, procurando cooptar os trabalhadores urbanos ao longo de toda década de 1930, criou primeiramente as leis de reforma das caixas de aposentadoria e pensões e, em seguida, os chamados Institutos de Aposentadorias e Pensões (IAP) para os diferentes tipos de trabalhadores como marítimos (em 1933), comerciários (em 1934), bancários (em 1934) e industriais (em 1936), para citar alguns exemplos.

No Brasil, portanto, a institucionalização da previdência social teve início com os ferroviários e, depois, a legislação previdenciária se estendeu aos portuários e aos trabalhadores da navegação fluvial e marítima por meio da lei 5.109, de 20 de dezembro de 1926. As leis relativas à organização do trabalho, bem como a criação das caixas de aposentadoria e pensões, já eram uma realidade na Europa do século XIX por volta de 1820 e, sobretudo, entre 1840 e 1850, quando a situação dos trabalhadores nas principais cidades industriais passava a exigir certo grau de proteção social. À época, os estados europeus estavam diante de um embate de forças onde, de um lado, havia trabalhadores relativamente organizados e combativos e, de outro, proprietários fabris que buscavam de todas as formas aumentar seus lucros e reduzir custos de produção. À margem desse embate, no entanto, havia uma massa de operários miseráveis que tinha sido expulsa do mercado de trabalho ou ansiava nele adentrar.

O direito à aposentadoria representou no Brasil um grande benefício para a classe dos trabalhadores e, primeiramente, para os ferroviários. Aliado ao conjunto de mazelas vividas pelos ferroviários como outras categorias profissionais contemporâneas, longas jornadas de trabalho e podiam chegar a quarenta anos de serviços sem receber qualquer tipo de compensação em termos de benefício, a aposentadoria foi concedida em função das inovações tecnológicas, como nos alerta Segnini (1982), porque o "ferroviário que não tivesse condições físicas ou psíquicas de acompanhar a introdução da eletrificação, na Paulista, seria afastado de seus trabalhos, desde que com tempo suficiente para se aposentar" (p. 57).

\section{MORADIA E PATERNALISMO: AS VILAS FERROVIÁRIAS}

Tratamos nas duas seções anteriores acerca dos principais instrumentos de controle laboral implementados pelas empresas ferroviárias paulistas como as cooperativas, as escolas de formação profissional e os fundos de pensão e aposentadoria. Agora, nesta seção, discutiremos a questão da 
habitação dos ferroviários e, para isso, analisaremos principalmente as segunda e terceira fases da Companhia Paulista, como apontado por Segnini (1982), e o modo de provisão das casas pela direção da empresa. 8

Embora este estudo tenha como objeto específico a Paulista, a construção de vilas operárias não foi uma política paternalista exclusiva dessa companhia, ou das empresas de estradas de ferro do país em geral, pelo contrário, tal prática também foi comumente adotada por empresas de outros setores econômicos no Brasil durante o período entre os anos de 1920 e 1940. No estado de São Paulo, cinco grandes companhias privadas foram reunidas em uma única empresa dirigida pelo governo estadual em 1971, que veio a se chamar Ferrovia Paulista S.A. (FEPASA). Segundo Morais (2002, p. 119), as ferrovias da FEPASA possuíam juntas 5752 casas construídas e situadas em 210 municípios. Além disso, o autor traz dados comparativos entre os números de unidades habitacionais construídas por cidade e ferrovia. Em número totais, têm-se o seguinte: Estrada de Ferro Sorocabana, 2784 unidades; Companhia Paulista, 1666 unidades; Companhia Mogiana, 809 unidades; Estrada de Ferro Araraquara, 412 unidades; Estrada de Ferro São Paulo-Minas, 81 unidades. Além do número de unidades construídas, a Paulista chama a atenção pela abrangência geográfica, pois a empresa formou vilas ferroviárias em 62 municípios.

Apesar de importante, há que se fazer uma ressalva aos dados de Morais (2002), pois este contabilizou apenas os dados dos imóveis existentes até a década de 1960, excluindo-se assim as casas que foram vendidas ou que poderiam ter sido demolidas com o passar do tempo. Os dados dos relatórios da Companhia Paulista contabilizam 3744 unidades de 1904 a 1928, entre casas de empregados e casas de turma (Companhia, 1905). É a partir de 1904 que as casas de empregados passam a ser arroladas nos relatórios junto às estações. No ano de 1903, a Paulista possuía 114 estações ao longo de 1029 quilômetros de extensão de linhas e, também, um total de 4077 empregados. A partir de 1929, ano marcado pela crise internacional que abalou o mercado de café (principal produto transportado pelas ferrovias paulistas), o ritmo de construção de casas cai consideravelmente. Os anos nos quais se registrou o maior número de construções foram: 1923, com 409 unidades e 1925, com 411 unidades construídas (Companhia, 1924). No relatório de 1924, há inclusive o seguinte trecho:

A intensa crise de habitações que nos últimos tempos se tem manifestado em todas as cidades do interior, determinada não só pela sensível falta de casas, como pelo extraordinário encarecimento dos alugueis, tem creado sérias difficuldades ao pessoal ferroviário, sobretudo nos centros de maior aglomeração de operários e trabalhadores. Em Itirapina, São Carlos, Araraquara e Rincão, o problema agravou-se sobremodo, por estarem situadas nessas localidades importantes estações de baldeação, cujo serviço desenvolveu-se consideravelmente com a installação dos armazéns reguladores de café. Empenhada em dar ao problema solução capaz de resolve-lo em suas differentes modalidades, isto é, offerecendo aos seus auxiliares habitação hygienica, a preço módico e junto ao trabalhado, único meio de tornar o pessoal estavel e garantir a regularidade dos serviços a cargo da Companhia, principalmente nas estações de baldeação, em que é necessário manter grandes turmas de trabalhadores, geralmente compostas de gente que não prima pela constancia no serviço - vem a Directoria, já de alguns annos a esta parte, promovendo a construção de casas em larga escala em diferentes

\footnotetext{
${ }^{8}$ A análise presente nesta seção deriva da tese de doutoramento de um dos autores deste artigo. A respeito, ver Inoue (2016).
} 
pontos da linha, e, pelos, bons resultados colhidos, julga dever continuar a faze-lo. Assim é que autorisou a construcção de duzentas casas e dez novas habitações de vários typos. Serão essas casas construídas em terreno que a Companhia já possue, devendo cada uma custar, em média, cerca de 5:800\$000. Realizando a construcção de taes habitações e offerecendo-as ao uso do pessoal, mediante aluguel correspondente a um rendimento razoável do capital empregado, a Companhia attende a uma imperiosa necessidade dos serviços a seu cargo, satisfaz as mais palpitantes conveniências de seus auxiliares e applica o seu capital em condições de fazer crescer a sua receita em justa proporção com o valor de seu patrimônio (Companhia, 1910, pp. 13-14).

A importância das vilas operárias está na configuração dos primeiros núcleos urbanos que surgiram com o estabelecimento das linhas férreas. Tais núcleos são verdadeiras testemunhas patrimoniais não apenas da história da arquitetura e do urbanismo, mas também das relações sociais subjacentes que se refletem na configuração dos espaços que entremeiam trabalho, lazer e descanso de seus residentes. Um dos aspectos que chamamos à atenção é o de como o paternalismo também marcou o projeto das vilas ferroviárias e, portanto, o modo de provisão das casas para os trabalhadores que, incialmente fornecidas pelas empresas, passaram, num segundo momento, a serem ofertadas pelo Estado.

A finalidade precípua das vilas ferroviárias era manter o trabalhador perto do local de trabalho, particularmente em locais que exigiam um número grande de trabalhadores e para a realização do trabalho frequente de manutenção das linhas. Locais como as oficinas, os armazéns, os entroncamentos de duas ou mais estradas de ferro, locais de baldeação entre linhas de bitolas diferentes ou ainda entre linhas eletrificadas e não-eletrificadas, costumavam reunir um grande contingente de trabalhadores e, por conseguinte, havia uma demanda maior por moradia.

Nem todos os trabalhadores moravam nas vilas. As casas só eram disponibilizadas aos ferroviários cujos trabalhos tinham relação direta com a manutenção e operação dos trens. Eram os chamados empregados de emergência: maquinistas, guarda-trens, foguistas, ajustadores, eletricistas e pessoal da estação (Companhia, 1923). Raros eram os engenheiros que habitavam nas vilas ferroviárias, pois estas eram dirigidas sobretudo aos chefes de estações e trabalhadores. Este aspecto revela um sistema divisionário, como o implantado pelas ferrovias nos Estados Unidos desde 1850, do qual fala Chandler (1998), e que também foi adotado pela Companhia Paulista, a partir de 1928, juntamente com os princípios tayloristas, separando assim as funções técnicas das funções administrativas (Garcia, 1992, pp. 67-68). No caso da Paulista, dos 62 municípios que possuíam vilas ferroviárias, as cidades estratégicas para a ferrovia pelos motivos acima expostos (entroncamento, oficinas, armazéns) eram: Jundiaí (cidade inicial da linha da Paulista e que abrigava a sua principal oficina), Dois Córregos (local de baldeação entre linhas não-eletrificadas e eletrificadas), Rio Claro (cidade onde se localizava a sua oficina de construção e manutenção) e Itirapina (cidade dotada de armazém de café). Além destas, Bauru e Araraquara também eram extremamente importantes em virtude dos entroncamentos com outras companhias de estradas de ferro.

Uma tipologia tipicamente ferroviária são as chamadas casas de turma; em geral, duas ou no máximo um conjunto de quatro casas, construídas entre as estações ao longo das vias e destinadas aos trabalhadores responsáveis pela manutenção das linhas férreas ou pelo atendimento urgente, em casos de acidentes. 
Ao se aposentar, o ferroviário era obrigado a desocupar as casas das vilas. Era comum repassálas aos filhos que fossem seguir a mesma profissão. Para precaver-se quando da aposentadoria, o ferroviário, ao longo da sua vivência na vila, costumava construir uma outra casa, sobretudo aos finais de semana, com o auxílio de outros operários e inclusive com a ajuda da própria companhia que, mediante a Seção de Engenharia, fornecia a planta da casa gratuitamente, ao passo que o material de construção deveria ser pago por prestações que iam sendo descontadas do salário mensal (Garcia, 1992, p. 178). Há ainda relatos sobre a construção de casas para venda pela própria Companhia Paulista, porém tal procedimento não era muito usual (Losnak, 2003). Isso ocorria em momentos de inflação crescente e de escassez habitacional frequente em muitas cidades paulistas, fazendo com que a companhia construísse mais casas para não ter que aumentar ainda mais sua folha de pagamento, como se observou na década de 1950.

Como as casas das vilas ferroviárias eram dirigidas apenas àqueles trabalhadores especializados, ou eram concebidas para atender outros propósitos da companhia, nem todos conseguiam morar nessas vilas e, não raro, os trabalhadores ficavam em listas de espera, segundo testemunhos de exferroviários $9^{9}$ Assim, paralelamente às vilas ferroviárias, surgiram outras estruturas habitacionais que não necessariamente estavam ligadas às indústrias, mas que eram produzidas por empreendedores privados para serem alugadas aos trabalhadores. A atividade de construir e alugar casas foi bastante lucrativa para os padrões econômicos da época dado o seu caráter especulativo até aproximadamente 1942, quando se sancionou uma lei de controle dessa atividade rentista, a chamada Lei do Inquilinato. 10

Na implantação da vila ferroviária, pode-se observar alguns elementos espaciais que refletem a hierarquia entre os trabalhadores. Por exemplo, as áreas da casa e do terreno do chefe da estação, ou chefe de linha, eram sempre maiores que as áreas das casas dos demais funcionários, apresentando recuos frontais e laterais, além de alguns ornamentos arquitetônicos que as diferenciavam das demais habitações. Tais casas também eram construídas em locais estratégicos para facilitar a vigilância sobre o trabalho coletivo dos operários, como as esquinas das quadras nas vilas de grandes proporções (ver figura 1).

Os programas das casas eram muito simples e invariavelmente constituídos de dois dormitórios, sala, cozinha, banheiro (este podendo ser interno ou externo). Algumas casas mais antigas apresentavam forno à lenha na cozinha, podendo ser observadas chaminés na parte externa. Construídas no período de grande preocupação sanitarista, havia casas que possuíam um pequeno porão. Este elemento pode ser verificado em algumas das casas da vila ferroviária da cidade de Rincão, que apresentam porão e assoalho de madeira. Muitas eram dotadas de um quintal nos fundos (ver figuras $2,3 \mathrm{y} 4$ ).

Dentre as ideias tayloristas difundidas pelo IDORT, algumas se voltavam para a questão habitacional. Havia, por exemplo, uma orientação que dava preferência às casas isoladas nos lotes ao invés de habitações coletivas, denotando certo preconceito em relação à convivência em prédios com mais pavimentos, que perdurou até a década de 1940. Defendia-se a habitação com quintal ao fundo para o cultivo de hortas pelos trabalhadores, pois acreditava-se que tal atividade poderia manter o trabalhador e a família mais tempo no domicílio, afastando-os dos vícios. A propósito, tal ideia aparece em um artigo veiculado durante o Congresso Pan-Americano de Estradas de Ferro,

\footnotetext{
${ }^{9}$ Ver em Ferreira (2010), Tenca (2006) e Zambello (2005).

${ }^{10}$ A Lei do Inquilinato foi uma lei federal que congelou o preço dos aluguéis, entre outras regulações. Para maiores detalhes ver Bonduki (1998).
} 
FIGURA 1. CASA DO CHEFE DA ESTAÇÃO DE JAÚ (SP)

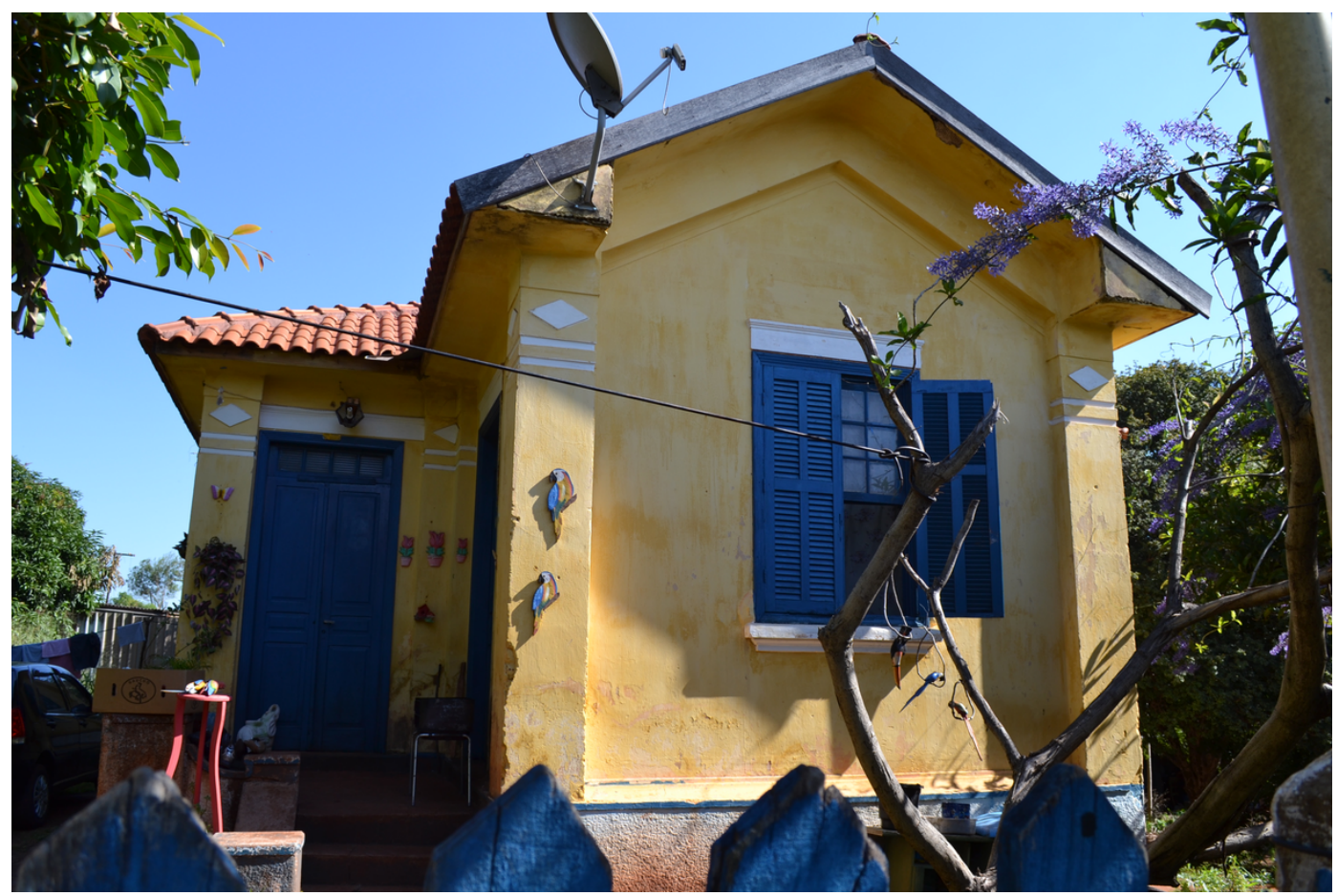

Autor: Inoue (2013).

no final da década de 1950, no qual o engenheiro uruguaio Franco Vasquez defende a importância dos quintais, juntamente com as associações e clubes, como elementos estratégicos para afastar os trabalhadores dos vícios 11

Há autores que consideram essa política de construção de casas operárias pelo empresariado das ferrovias uma clara evidência de paternalismo (Drummond, 1995). Havia muita ingerência das empresas na vida dos trabalhadores, mesmo na Companhia Paulista durante a fase de 1928 a 1961, marcada pela organização racional do trabalho. Esta ingerência paternalista passou a assumir outra roupagem sob o lema formação integral do trabalhador, defendida por Roberto Mange. Outros autores, como Segnini (1982) preferem chamar tal ingerência de introjeção da moral patronal aos trabalhadores. A ideia da família ferroviária, que aparece em vários relatos de trabalhadores, parece corroborar essa concepção de formação integral ou introjeção da moral patronal. Dentre os recursos patronais utilizados para incutir essa ideia de pertencimento a uma família, havia a proposta (manifesta no discurso da gerência ferroviária) de unir a instrução, os laços familiares e a promoção dentro da hierarquia empresarial. Os que já tinham membros da família trabalhando na ferrovia, tinham preferência no ingresso nas escolas ferroviárias. Na promoção, tinha-se preferência pelos funcionários casados aos solteiros, alegando-se que os primeiros eram mais responsáveis:

\footnotetext{
${ }^{11}$ Vasquez, Franco P. (1958). Bem estar e moral do pessoal. Revista Ferroviária, ano xix (12), pp. 61-62.
} 
FIGURA 2. CASA DA VILA FERROVIÁRIA DE JAÚ (SP)

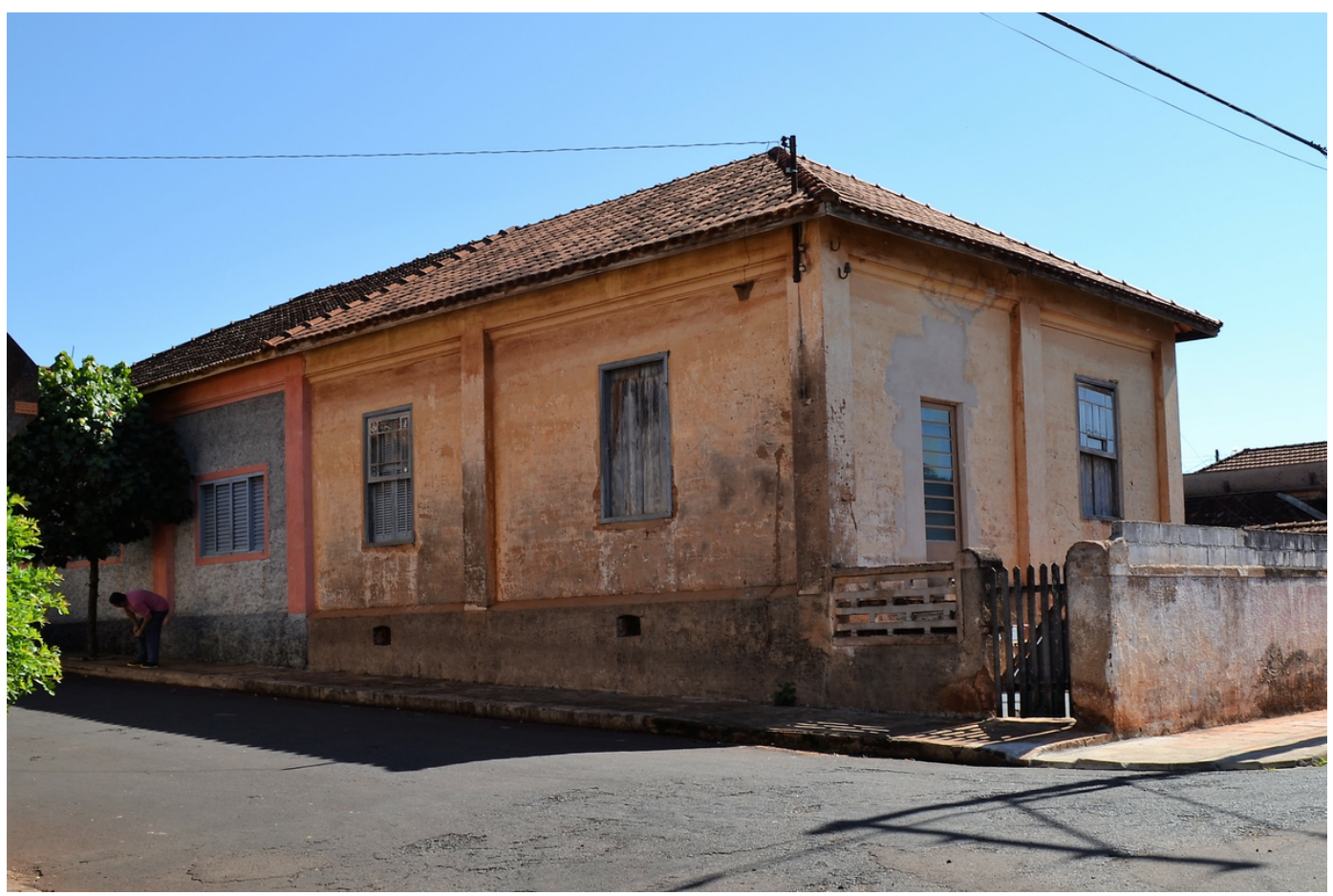

Autor: desconhecido.

As sanções aos ferroviários não se limitavam à observância de um determinado comportamento somente dentro da empresa. A nível pessoal e familiar, ela também era exercida. Assim os cargos de chefia só eram entregues a operários casados, sob a alegação de que estes eram possuidores de maior responsabilidade, portanto, tidos como mais aptos para o exercício da tarefa de controle sobre os demais. A separação entre o casal acarretaria boicotes, por parte da empresa, ao ferroviário (Segnini, 1982, p. 80).

Nota-se também a tal introjeção moral no depoimento de um ex-funcionário:

[...] antigamente havia respeito na Paulista: ferroviário não entrava na sala da Diretoria, não bebia, não largava mulher, nem abandonava os filhos. Se não, já sabia: ou era repreendido ou mandado embora. Não era esta bagunça que é hoje (Depoimento de ex-ferroviário não identificado. In Segnini, 1982, p. 80).

Nas vilas ferroviárias da Companhia Paulista, os ferroviários casados também tinham preferência para ocupar as casas em detrimento dos solteiros. Raramente encontrava-se nas vilas os chamados alojamentos para solteiros. O aluguel era descontado do salário e, de acordo com Segnini (1982, p. 59), o aumento salarial era calculado com base naqueles empregados sem casa, com casa, e os não efetivos, ou jornaleiros. Mesmo com salários deprimidos em virtude da existência de benefícios tais como a casa, a cooperativa e o clube recreativo, e também por certa estabilidade 


\section{FIGURA 3. CASA DO CHEFE DA ESTAÇÃO DE DOIS CÓRREGOS (SP)}

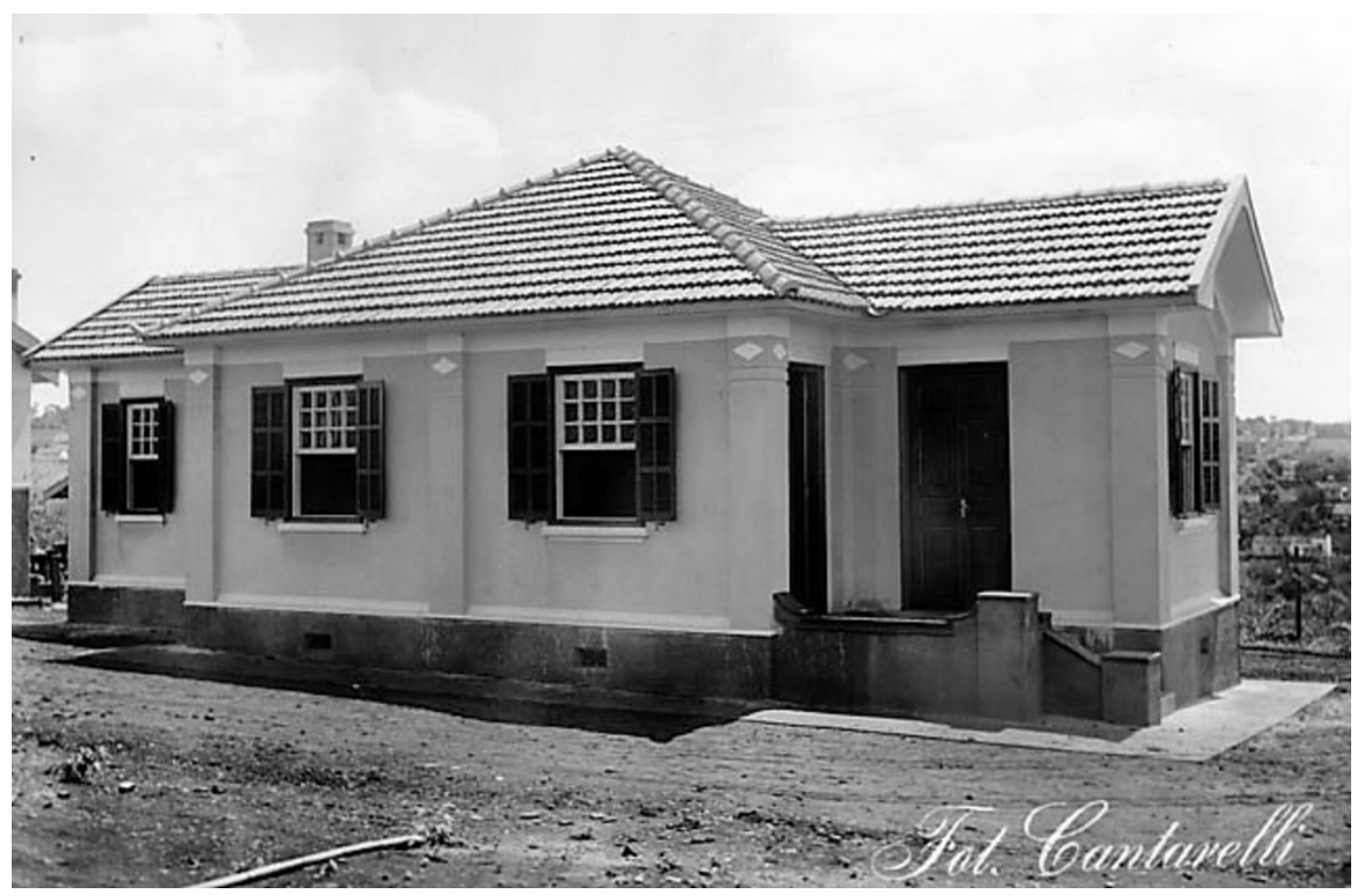

Autor: Inoue (2013).

no emprego, ou ainda por ser uma das poucas grandes empresas da cidade onde se residia, muitos trabalhadores optavam por continuar como operários de baixa remuneração para a realização dos trabalhos mais diversos na Paulista, conforme observado por Garcia (1992, pp. 36, 146).

Trabalhar na ferrovia era motivo de orgulho e sinônimo de status social, bom emprego e estabilidade. Sendo assim, muitos filhos de ferroviários continuavam trabalhando na companhia permanecendo como moradores das vilas. ${ }^{12}$ Consequentemente, era comum que muitas das casas passassem de uma geração à outra. Outro aspecto que reforça a ideia da família ferroviária reside no fato dos funcionários da empresa passarem a maior parte do tempo no trabalho ou nas vilas ferroviárias. Portanto, a separação entre o trabalho e a casa era tênue. O tempo livre também era desfrutado em conjunto com outros ferroviários e suas famílias. Os principais tipos de diversão eram o futebol e os grêmios recreativos, onde se realizavam várias atividades tais como cinema, baile dançante e outras atividades esportivas. Os equipamentos de lazer eram, via de regra, resultantes da iniciativa dos próprios operários que se juntavam para arrecadar o dinheiro das construções e, em apenas alguns casos, a Companhia Paulista cedia o terreno ou concedia alguma contribuição, haja vista que tais equipamentos ajudavam a reforçar a própria ideia da família ferroviária.

${ }^{12}$ Aqui infelizmente não há dados quantitativos, porém há uma confluência nos depoimentos de ex-ferroviários de diferentes companhias ferroviárias, apresentados por estudos de cunho sociológico, como Garcia (1992), Ferreira (2010) e Losnak (2003), o que nos leva a corroborar a perpetuação de gerações em uma mesma vila. Inclusive, em uma visita de campo, realizada em 2013, a algumas das vilas ferroviárias do interior paulista, verificamos a presença de algum familiar de ex-ferroviários ocupando a casa, mesmo com a desativação da ferrovia já há alguns anos. 


\section{FIGURA 4. CASA DA VILA FERROVIÁRIA DE RINCÃO (SP)}

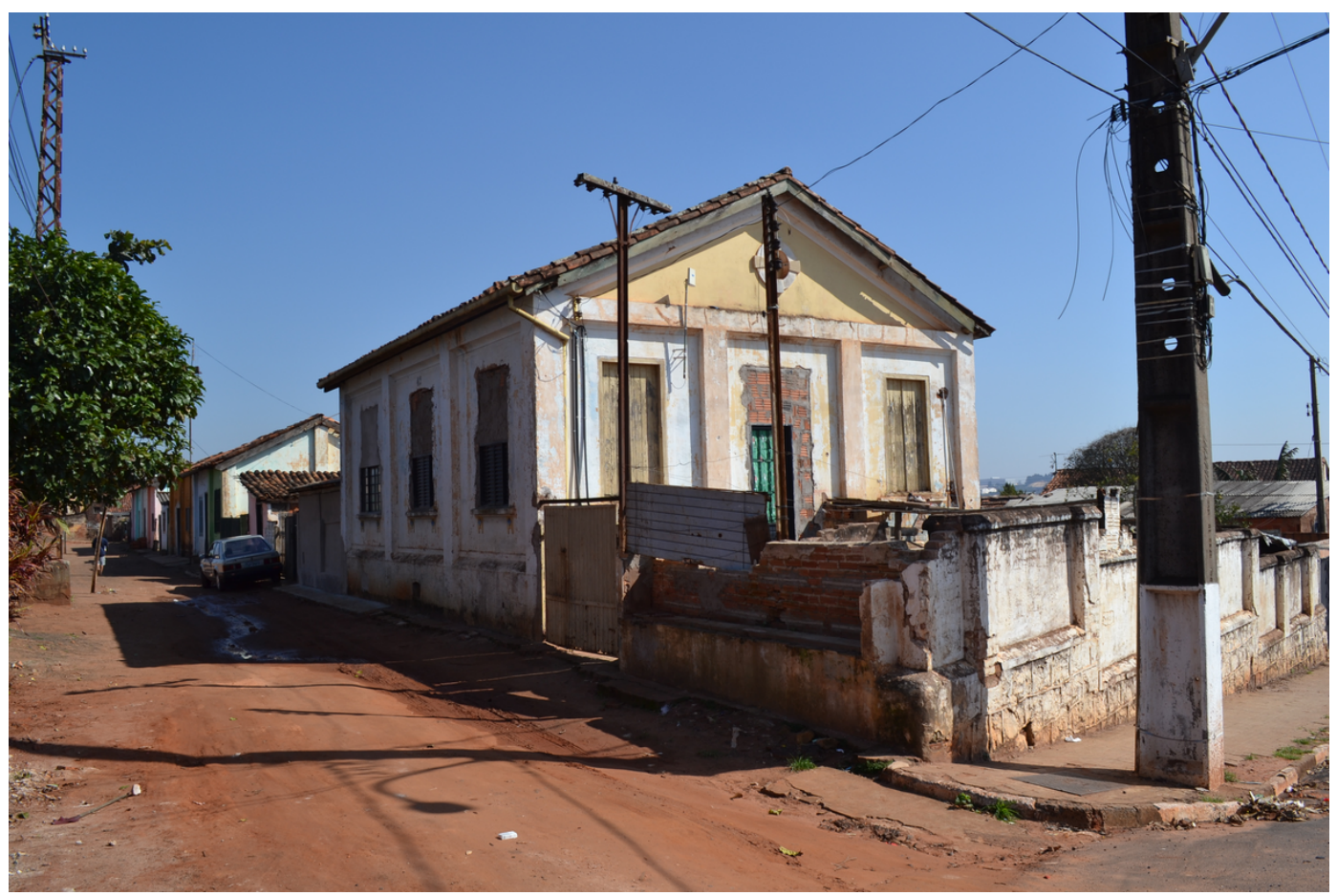

Autor: Inoue (2013).

Esta concepção reforçava a hierarquia ocupacional no interior da empresa, contraditoriamente com as noções de proximidade e de veneração: proximidade dos trabalhadores aos chefes e engenheiros e de veneração dos trabalhadores para com seus superiores. Tal concepção permaneceu até o final da existência da Companhia Paulista como empresa privada, ou seja, até 1961. Muitos cargos administrativos foram concedidos segundo critérios escusos como resultado do apadrinhamento político. Havia uma rotatividade considerável nos cargos de chefia para os quais determinados quadros não apresentavam conhecimento prático suficiente, o que também gerava conflito entre seus subordinados.

Do ponto de vista da arquitetura e do urbanismo, dois debates influenciaram a implementação das vilas operárias. O primeiro deles se vincula às questões sanitaristas, dentro das quais vários atores sociais, políticos, engenheiros e médicos formularam modelos do que deveria ser a casa operária. Segundo estes, a casa operária deveria ser econômica, higiênica e moral (afastando o trabalhador dos vícios). Tais questões foram debatidas no Primeiro Congresso Brasileiro de Habitação em 1931. Contudo, o debate e as formulações sobre a habitação dos operários não pararam por aí. Um segundo grande marco foi a Jornada de Habitação Econômica promovida pelo IDORT em 1941. Neste último evento, nota-se a presença marcante de industriais nos debates sobre moradia. Debates esses que gravitavam em torno da forma de acesso do trabalhador à casa, isto é, se alugada ou própria. 
Nessa Jornada de 1941 foi importante o discurso de Roberto Simonsen (um dos fundadores do IDORT), em que o empresário defendeu a ação do Estado no campo da moradia popular. Como observa Correia (2004):

A ação do IDORT se inscreve, ainda, em um momento especial da ação dos industriais no campo da moradia do trabalhador. Até os anos 1930, tal ação fundamentava-se sobretudo em iniciativas individuais, voltadas especialmente à construção de vilas operárias e núcleos fabris junto a plantas industriais, e a um esforço de promoção desses lugares perante a opinião pública como ilhas de ordem e bem-estar. A partir dos anos 30 - já ocupando posição hegemônica na sociedade brasileira -, os industriais vão se empenhar em ampliar esta ação. Agora não se trata apenas de construir vilas e núcleos fabris e de mostrá-las como indício de um progresso e de um bem-estar propiciados pela indústria, mas especialmente influir na ação de outros setores do capital e na do Estado em relação à questão da moradia operária... (p. 100).

Acreditava-se que a ação do Estado referida na Jornada de Habitação deveria ser entendida no sentido do financiamento e da produção da moradia operária para a venda. Na ocasião, de acordo com Correia (2004, p. 98), Simonsen "alertava para o perigo de o pagamento da casa própria absorver elevadas parcelas dos rendimentos dos trabalhadores, sacrificando a satisfação de outras necessidades, e recomendava para os mais pobres, casas adequadas com aluguel acessível às suas posses". Posição semelhante era a do presidente do Instituto dos Industriários à época, Plínio Castanhede, que recomendava uma análise caso a caso, de compra ou aluguel da casa pelo trabalhador, mas, ao mesmo tempo, enfatizava a importância de o trabalhador possuir sua própria casa (Correia, 2004, p. 97).

Entre os defensores da casa própria, tinham aqueles que questionavam como garantir a compatibilidade com os salários baixos, ao passo que outros defendiam que os recursos provindos de economia popular, como caixas econômicas, companhias de seguros e institutos de previdência, deveriam ser alocados para a fim habitacional. Havia também contemporâneos que afirmavam não ser a falta de recursos o problema central, mas em um certo comodismo e ignorância de alguns trabalhadores por não saberem poupar visando adquirir uma casa, já que os salários seriam suficientes para a amortização de uma residência de pequeno vulto em zona suburbana (Correia, 2004, pp. 97-98). Sabe-se, no entanto, que por volta de janeiro de 1942, para um trabalhador urbano o aluguel representava cerca de $30 \%$ dos gastos domiciliares de uma família de classe média. Já para uma família de classe média superior, o aluguel representava aproximadamente 15\% da renda familiar. Segundo Gusmão (1944):

Não obstante ser o aluguel uma parcela importante, nem sempre tem a mesma significação em todo e qualquer orçamento. Isto porque o preço da habitação não é sempre proporcional às rendas auferidas. Quem percebe mensalmente uma renda igual ou superior a Cr\$ 10000 pode viver bem instalado pagando um aluguel mensal de 1500 cruzeiros... (p. 86).

Infelizmente, não temos dados de aluguéis para o interior de São Paulo, onde as vilas ferroviárias estavam localizadas, porém temos outros dados para a área urbana, especificamente para a cidade de São Paulo. Em anúncios do jornal O Estado de São Paulo (1943) encontramos informações sobre casas em áreas centrais da cidade de São Paulo, voltadas para trabalhadores urbanos, 
cujos aluguéis variavam entre $\mathrm{Cr} \$ 560.00$ a $\mathrm{Cr} \$ 640.00$ (Inoue, 2010, p. 137). Com relação aos salários, temos o seguinte dado: em 1937, segundo material colhido pelo Instituto de Aposentadoria e Pensões dos Industriários (IAPI) e apresentado na revista Observador Econômico (1949, p. 4), mais de 36\% dos operários brasileiros recebiam salários mensais que iam de 100 a 199 cruzeiros, quase $23 \%$ recebiam menos de 99 cruzeiros, e pouco mais de $21 \%$ entre 200 e 299 cruzeiros. Dez anos depois, em 1947, e de acordo com o mesmo IAPI, a maior parcela de operários, segundo o critério de salário, encontrava-se na faixa que recebia entre 300 a 399 cruzeiros mensais.

Com relação ao Estado como provedor de moradia aos trabalhadores, observa-se que os fundos de pensão criados também eram utilizados com o propósito de atender a demanda por moradia. O funcionamento das Caixas de Aposentadorias e Pensões (CAP), criadas em 1923 pelo governo federal, passou por mudanças em 1931 e, no ano seguinte, um decreto federal (Correia, 2004, pp. 97-98) aprovou o regulamento para a aquisição e construção de casas populares pela

CAP. Estas foram transformadas nos Institutos de Aposentadorias e Pensões (IAP) em 1933 e, em 1937, aprovou-se novamente outro regulamento para a aquisição de prédios destinados às sedes dos IAP e à moradia dos associados.

Assim, pouco a pouco, as indústrias vão ao longo dos anos 1930 se desincumbindo da responsabilidade de prover habitação para seus trabalhadores, deixando essa função a cargo do Estado e da própria iniciativa dos trabalhadores. Chega-se ao Estado Novo, em 1937, já com a ideologia da casa própria fortemente disseminada. Nota-se que a produção de moradia pelas CAP e, posteriormente pelos IAP, eram para a venda, tornando assim o trabalhador um pequeno proprietário. Após a Lei do Inquilinato (em 1942), a produção de casas para aluguel diminui levando muitos empreendedores imobiliários de volta para a produção de casas com o objetivo de venda.

Assim, diante dos fatos e especificidades apontados acima, pode-se aludir que a construção das vilas ferroviárias, embora tenha ocorrida durante toda a existência da Companhia Paulista (18681961), deu-se de maneira mais intensa ao longo dos anos 1920, pois, a partir deste marco, a forma de provisão de habitações pela empresa se alterou profundamente. Há relatos da construção de 120 casas em Rincão em 1921 e a própria Paulista atesta a ocorrência de construções em 1924 e 1925, especialmente devido à instalação de armazéns de café junto às estações, demandando assim novos trabalhadores. O declínio da construção de vilas ferroviárias deu-se no decorrer dos anos 1930 por três motivos: a crise do café, o principal produto transportado pelas ferrovias; a consolidação da rede ferroviária paulista, levando as empresas a se envolver cada vez menos com a questão habitacional; e o início da execução de uma política habitacional capitaneada pelo Estado que, portanto, passou a assumir a provisão de casas aos trabalhadores, antes realizado pelas companhias ferroviárias dentre outras empresas de setores diversos da economia que se envolveram na constituição de vilas operárias por todo o Brasil.

\section{Conclusĩo}

Ao longo do artigo analisamos os principais instrumentos de controle laboral exercido pela Companhia Paulista sobre seus trabalhadores, corporificados em medidas paternalistas como as escolas de formação e aprendizagem, as cooperativas de consumo, a sociedade beneficente, os fundos de pensão e as vilas ferroviárias. Pode-se dizer que tais instrumentos faziam parte de um modelo amplo de organização e controle do trabalho ferroviário. Demos, contudo, um enfoque maior às vilas ferroviárias em virtude da diminuta atenção que essa estrutura urbano-habitacional tem recebido por parte dos estudos que abordam os temas da constituição e desenvolvimento das empresas 
ferroviárias de São Paulo e das relações de produção fundamentadas no conceito de paternalismo. Enfatizamos também a importância que empresas como a Paulista tem para a história da institucionalização das caixas de aposentadorias e pensões. O pioneirismo das companhias ferroviárias nesse campo teve implicações importantes para a definição posterior da legislação nacional sobre essa questão social.

O principal traço do caráter neo paternalista das relações de produção das ferrovias paulistas é a ideia de família ferroviária, noção estreitamente vinculada às vilas ferroviárias. Em verdade, ela se origina no interior das vilas entre os operários residentes, portanto, é resultante da própria conduta paternalista das empresas. Aliado a isso, convém esclarecer a definição conceitual de paternalismo: a existência de uma cultura de identificação dos trabalhadores com a empresa na qual se trabalha que inspira respeito e admiração por ela. É esse sentimento de pertencimento à família ferroviária, evidenciado por alguns depoimentos de ex-ferroviários, de fidelidade à moral e à filosofia da corporação, que nos leva a defender nosso principal argumento neste artigo. Em suma, o lócus por excelência dessa cultura paternalista criada pelas principais empresas ferroviárias de São Paulo são as vilas e os bairros ferroviários espalhados por inúmeras cidades do interior paulista. Segundo um apêndice de Morais (2002), a FEPASA abrangia 218 municípios 13 destes, e como já notamos anteriormente, a Companhia Paulista esteve presente com suas vilas ferroviárias em 62 municípios.

Como instrumento de controle laboral, a construção de casas pela Paulista foi realizada desde o início das operações da estrada de ferro. Elas se expandiram territorialmente ao longo do tempo com a ampliação das linhas e, principalmente, nas áreas ocupadas pela ferrovia onde a demanda por trabalhadores era maior, como nas oficinas, nos entroncamentos ferroviários, em lugares de baldeação e, na década de 1920, nos armazéns de café, o principal produto transportado. Os princípios de organização racional e científica do trabalho são introduzidos no Brasil nessa mesma década, nas escolas de ferroviários e se intensificam principalmente após 1931, ano da criação do IDORT, que reunia vários setores e atores sociais, além de industriais, médicos e educadores.

Vimos que questões sanitaristas também foram debatidas em torno do tema do provimento de casas aos operários, entre os anos de 1920 e 1930, sob forte influência dos princípios da organização racional do trabalho. Assim, a casa operária para além de econômica, higiênica e moral, deveria ser também produtiva. Pontuamos também que tais ideias foram debatidas em 1931 no Primeiro Congresso sobre Habitação e culminaram na Jornada de Habitação Econômica, promovida pelo IDORT em 1941.

Paralelamente, convém reafirmar que a legislação social no Brasil foi se transformando mais intensamente a partir de 1923 com a criação das Caixas de Aposentadorias e Pensões, que, em seguida, se transformaram nos Institutos de Aposentadorias e Pensões em 1933. Tais leis federais, juntamente com os debates que estavam ocorrendo à época, influenciaram em termos decisivos o modo de provisão e de acesso à habitação dos trabalhadores ferroviários e operários em geral, cuja provisão passou da empresa ao Estado e o acesso passou do aluguel à casa própria. Desse modo, ao longo da década de 1930, as indústrias em geral (e, principalmente, a ferroviária) vão deixando de construir tais vilas operárias até sua interrupção total que, por sua vez, coincidi com

${ }^{13}$ Atualmente, o estado de São Paulo possui 645 municípios. 
a crise do setor ferroviário na década de 1940 14 período também marcado pela implantação da política pública de habitação sob a responsabilidade do Estado e pela difusão da ideologia da casa própria.

Nesse sentido, se os anos 1920 testemunharam o auge das práticas paternalistas de controle e disciplinamento da mão de obra ferroviária em São Paulo, evidenciado pelos projetos de construção de casas operárias ${ }^{15}$ as duas décadas subsequentes estiveram marcadas pela ressignificação dessas práticas empresariais sob a influência dos princípios tayloristas, que, por meio dos métodos de racionalização da organização do trabalho, passou a perseguir, e conquistar de modo crescente, maiores índices de produtividade do serviço ferroviário como um todo. Estratégia essa que colocou a Paulista entre as ferrovias mais produtivas e bem gerenciadas do país até o final dos anos 1950 (Grandi, 2013). Este ganho, no entanto, se viabilizou em virtude do processo bem-sucedido de reinvenção do paternalismo efetivado por grandes empresas de destaque em seus segmentos industriais, como foi o caso aqui exposto da Companhia Paulista de Estradas de Ferro.

\section{REFERÊNCIAS}

Antonacci, M. A. (1987). Institucionalizar ciência e tecnologia - em torno da fundação do IDORT (São Paulo, 1918/1931). Revista Brasileira de História, 8(14).

Antonacci, M. A. (1993). A vitória da razão (?): O IDORT e a sociedade paulista. São Paulo: Marco Zero.

Bonduki, N. G. (1998). Origens da Habitação Social no Brasil. Arquitetura Moderna, Lei do Inquilinato e difusão da casa própria. São Paulo: Estação Liberdade.

Caetano, C. G. (1986). Qualificação e ferrovias: a experiência das Escolas Profissionais Ferroviárias (1920-1945). In M. A. R. Ribeiro (org.), Trabalhadores Urbanos e Ensino Profissional (2 ed.). Campinas: Ed. da Unicamp.

Chandler, A. (1998). As Estradas de Ferro: pioneiras da moderna administração de empresas. In T. McCraw (org.), Alfred Chandler - Ensaios para uma teoria histórica da grande empresa. Rio de Janeiro: FGV.

Companhia Paulista de Vias Férreas e Fluviais (1905). Relatorio num. 56 para a sessão de Assembléa Geral em 30 de junho de 1905. São Paulo: Casa Vanorden.

Companhia Paulista de Vias Férreas e Fluviais (1910). Relatorio num. 61 para a sessão de Assembléa Geral em 30 de junho de 1910. São Paulo: Casa Vanorden.

Companhia Paulista de Vias Férreas e Fluviais (1923). Relatorio num. 74 para a sessão de Assembléa Geral em 22 de junho de 1923. São Paulo: Casa Vanorden.

Companhia Paulista de Vias Férreas e Fluviais (1924). Relatório num. 75 da Diretoria da Companhia Paulista de Vias Férreas e Fluviais apresentados à Assembléia Geral dos Acionistas. São Paulo: Casa Vanorden.

Correia, T. B. (2004). A construção do habitat moderno no Brasil - 1870-1950. São Carlos: Rima.

\footnotetext{
${ }^{14}$ Matos (1974); Saes (1981).

${ }^{15}$ Sobre a Companhia Sorocabana, Moreira (2008, pp. 61-62) nota que: “A empresa também passou a investir nas questões de habitação, alimentação e saúde de seus funcionários. Em 1925, iniciou-se o investimento na construção de sedes de residências, casas de turmas e de mestres de linha, casas para o pessoal das estações etc., que se prolongou até 1930 e foi retomada na gestão de Gaspar Ricardo Junior, em 1933 [... ] Além disso, buscou-se, por meio da construção de casas limpas e higienizadas, moralizar e higienizar as condições de vida dos ferroviários. Esse empreendimento possibilitaria um controle de vigilância maior sobre os atos dos ferroviários quando estivessem fora do trabalho”.
} 
Craven, P. e Traves, T. (1986). Dimensions of Paternalism: Discipline and Culture in Canadian Railway Operations in the 1850s. In C. Heron e R. Storey (orgs.), On the Job: Confronting the Labour Process in Canada. Kingston/Montreal: McGill-Queen's University Press.

Drummond, D. K. (1995). Crewe: Railway Town, Company and People, 1840-1914. England: Scolar Press/Ashgate Publishing.

Ferreira, L. S. (2010). Entroncamento entre raça e classe: ferroviários no Centro Oeste Paulista 19301970 (Doutorado). Universidade Estadual de Campinas, Campinas.

Garcia, L. B. R. (1992). Rio Claro e as oficinas da Companhia Paulista de Estradas de Ferro: trabalho e vida operária 1930-1940 (Doutorado). Universidade Estadual de Campinas, Campinas.

Grandi, G. (2013). Estado e capital ferroviário em São Paulo: a Companhia Paulista de Estradas de Ferro entre 1930 e 1961. São Paulo: Alameda.

Grandi, G. (2014). The First Great Railway Strike: Rereading the Early Labour Movement in São Paulo. International Review of Social History, 59(22).

Gusmão, A. A. C. (1944). Câmbio negro das locações. Observador Econômico, 101.

Huberman, M. (1987). The Economic Origins of Paternalism: Lancashire Cotton Spinning in the First Half of the Nineteenth Century. Social History, 12(2).

Inoue, L. M. (2010). A iniciativa privada e o mercado formal de habitação para o trabalhador na cidade de São Paulo, 1942-1964 (Mestrado). Universidade de São Paulo, São Paulo.

Inoue, L. M. (2016). Fim da Linha? Vilas ferroviárias da Companhia Paulista (1868-1961): uma investigação sobre história e preservação (Doutorado). Universidade de São Paulo, São Paulo.

Joyce, P. (1980). Work, Society and Politics: The Culture of the Factory in Later Victorian England. London: Harvester Press.

Liga Operária de Jundiaí (1906). Acta da Assembleia extraordinária realizada no dia 16 de maio de 1906.

Losnak, C. J. (org.). (2003). Trabalho e sentimento: história de vida de ferroviários da Companhia Paulista e Fepasa. Bauru: Prefeitura de Bauru/Secretaria de Cultura.

Matos, O. N. (1974). Café e ferrovias: a evolução ferroviária de São Paulo e o desenvolvimento da cultura cafeeira. São Paulo: Alfa-Ômega.

Mattoon Jr., R. H. (1971). The Companhia Paulista de Estradas de Ferro, 1868-1900: a local railway enterprise in São Paulo (Doutorado). Yale University.

Morais, M. de. (2002). As vilas ferroviárias paulistas: arquitetura e as relações urbanas nos núcleos habitacionais (Mestrado). Escola Estadual de São Carlos/Universidade de São Paulo.

Moreira, M. F. S. (2008). Ferroviários, trabalho e poder. São Paulo: Unesp.

Revill, G. (2001). 'Railway Derby': Occupational Community, Paternalism and Corporate Culture 1850-90. Urban History, 28(3).

Saes, F. A. M. (1981). As ferrovias de São Paulo, 1870-1940: expansão e declínio do transporte ferroviário em São Paulo. São Paulo/Brasilia: Hucitec/INL.

Segnini, L. R. P. (1982). Ferrovia e ferroviários: uma contribuição para a análise do poder disciplinar na empresa. São Paulo: Autores Associados/Cortez.

Teixeira, D. L. P. (1984). A estrutura de poder, o paternalismo e o papel da assessoria técnica gerencial na pequena empresa industrial. Revista de Administração de Empresas, 24(2).

Tenca, A. (2006). Senhores dos trilhos: racionalização, trabalho e tempo livre nas narrativas de ex-alunos do curso de ferroviários da antiga Paulista. São Paulo: Unesp. 
Zambello, M. H. (2005). Ferrovia e memória: estudo sobre o trabalho e a categoria dos antigos ferroviários da Vila Industrial de Campinas (Mestrado). Faculdade de Filosofia, Letras e Ciências Humanas, Universidade de São Paulo, São Paulo.

Zanetti, A., e Vargas, J. T. (2007). Taylorismo e fordismo na indústria paulista: o empresariado e os projetos de organização racional do trabalho, 1920-1940. São Paulo: Associação Editorial Humanitas. 